\section{JSCM T \\ Journal of Sustainable Construction \\ Materials and Technologies}

J Sustain. Construct. Mater. Technol. 4(2) (2019) 372-378
Journal of Sustainable

Construction Materials

and Technologies

www.eds.yildiz.edu.tr/jscmt

\title{
Discovering hidden patterns in Turkish construction projects delays related to project characteristics
}

\author{
Ezgi Kazana, İsmail Cengiz Yılmaz, * \\ ${ }^{a, b}$ Istanbul Arel University, Istanbul, 34800, Turkey
}

Manuscript Received September 12, 2019; Accepted October 14, 2019

\begin{abstract}
There are delays in delivering construction projects, which have great affects in all countries' economies, due to many factors and reasons and these delays bring many negative consequences. Checking the source of these consequences or minimizing their effects is very important in terms of time and cost savings in the construction sector, especially for countries which have a continuous improvement such as Turkey. Determination of project factors that will cause delay, analysis of their impacts and taking protective measures will help to reduce losses. Hereby in this study, the project factors that may cause to delays are identified and some important association rules between these factors and delay are extracted by collecting the data from Turkish Public and private construction projects. Also, some recommendations were presented for reducing delays by using the extracted rules.
\end{abstract}

Keywords: Construction Projects, Delay Analysis, Apriori Algorithms, Association Rules

\section{Introduction}

The construction industry is the tool through which a society achieves its goals of urban and rural development [1]. To achieve these goals; it is very important for the construction sector to solve time and cost overrun problems. Because, time and cost overruns will negatively affect the quality of the construction project and bring many economic problems. Akogbe et al. (2013); concluded that construction overruns depend on different economic, political stability and management implementation and related to lack of technology, management, skills and competencies of project participants [2][3].

Resolving the economic problems of citizens or stakeholders involved in construction projects could be possible by reducing the delay time of projects. Because time is one of the most important factor affecting quality and cost. According to Mahamid (2011); delays not only affect project duration, but also increase costs and reduce construction quality [4]. Also, late completion of a project results in the overrun of the construction budget allocated at project inception as well as the delay of the potential income that could be obtained with the operation of the constructed facility [5]. While Marzouk and El-Rasa (2014) define delay as a time overrun either beyond the contract date or beyond the date that the parties have agreed upon for the delivery of the project [6], Trauner et al (2008); define it to make something happen later than expected to cause something to be performed later than planned or not to act timely [7].

In order to avoid from delays in construction projects, it is necessary to determine the route of the project by taking successful steps. Successful steps are possible by programming the project with the minimum error and planning in accordance with the schedule, but often this is not possible. For instance, Faridi and El-Sayegh (2006) determined that one of the two construction projects performed in the United Arab Emirates are

${ }^{*}$ Corresponding author:

E-mail address: cengizyilmaz@arel.edu.tr (Yılmaz, I.C.)

https://doi.org/10.29187/jscmt.2019.41 
delayed and not completed in time [8]; also Odeyinka and Yusif observed each 7 projects of 10 projects are delayed in their study [9].

Delays are a common problem in both public and private construction projects. Both sectors are unique in themselves. Because each project is unique and acts according to its specific plan and program. Due to this uniqueness, it is possible to encounter a different delay factor for each project. It is important to try to estimate these delay factors in the planning phase of the project and to shape the planning phase accordingly. For the planning phase and delays in this study; it was focused on 74 public and private projects from 2009 to 2018 and tried to gather some data related to these projects by analyzing them. The main contribution of this study is to draw meaningful rules by looking at the relationship between collected variables.

\section{Literature Review}

The number of projects successfully completed is very low as delay in construction projects is a common problem Many studies have been done in the literature to identify, analyze and resolve this problem. Sambasivan and Soon (2007) emphasized the problem of delays in the construction industry is a global phenomenon [10] and at literature it could be seen that delay factors are different for each country. Differences between countries may also cause different frequency and significance of causes [11]. Kazaz, Ulubeyli and Tuncbilekli (2012) applied a questionnaire survey in Turkey with 71 construction companies considering 34 delay factors. The top ten causes of time extensions were defined as; (1) Design and material changes, (2) Delay of payments, (3) Cash flow problems, (4) Contractor's financial problems, (5) Poor labor productivity, (6) Estimation problems, (7) Lack of feasibility studies, (8) Construction defects, (9) Unbalanced number of workers, (10) Fluctuation in material prices [5]. Doloi, Sawhney, Iyer and Rentala (2012) performed factor analysis and regression analysis according to the responses obtained from a survey conducted in India. As a result of these two analyzes, the most important delay factors were collected in such as; (1)lack of commitment, (2)inefficient site management, (3) poor site condition, (4)improper planning, (5)lack of clarity in project scope, (6)lack of communication, (7)sub-standard contract sub-headings [12].

Also Sunjka and Jacob (2013) defined the most important construction delay factors in Nigeria as; Youth unrest, militancy and communal crises, inadequate planning by the contractors, delay or non-payment of compensation to the communities, wrong choice of consultants and contractors by the clients, weather condition; poor contract management by the consultants, late identification and resolution of drawings and specification errors and omissions by the consultants, lack of community buy-in, poor contract management by the consultants, inappropriate design by the consultants, unrealistic contract duration by the clients and poor coordination of subcontractors by the contractors[13]. In order to determine the most important delay factors in Kuwait, Almutairi (2016); determined 40 delay factors and conducted a questionnaire survey by 22 participants. From the results obtained, the top 10 causes of delays in construction projects in Kuwait were summarized as; (1) Using a lowest price bidding and tendering system, (2) Poor performance of the main contractor, (3) Inadequate experience or qualifications of main contractor's staff, (4) Delay of payments from client to other parties, (5) Poor performance and management of subcontractors, (6) Shortage in the supply of general labour, (7) Frequent changes of subcontractors, (8) Delay in decision making by the client, (9) Conflict between the main parties to the contract, (10) Inappropriate methods used by the main contractor.[14]

Rezaei and Jalal (2018), in their studies at Iraq, determined 10 most important construction delay factors out of 61 factors as; (1) Security measures, (2) High number of contracts by the same contractor, (3) Poor labor productivity, (4) Design errors and discrepancies in contract documents, (5) Poor controlling of subcontractors by the contractor, (6) Material quality problems, (7) Uncooperative owner with the contractor or the consultant, (8) Inadequate qualification of the consultant to the project, (9) Inadequate early planning of the project, (10) Deficiency in drawings[15]. Naimi, M. (2016), also proposed a value engineering evaluation model to avoid delays and to reduce the project costs [16][17].

\section{Association Rule Mining}

The association rule is an approach that supports future studies by analyzing the previous data and identifying the relationship between these data [18]. Association rules can be effective in uncovering unknown relationships, and provide results for forecasting and decision making [19, 20]. The apriori algorithm developed by Agrawal and Srikant was presented in 1994 at the 20th VLDB (Very Large Database Endowment) conference. Apriori algorithm, which is the most known algorithm among association rule inference algorithms, is used for exposing large object sets. [21]. The name of the algorithm is Apriori derived from the word "prior" because it takes the information from the previous step [18]. Apriori algorithm is a frequently applied algorithm in sectors such as construction, health, banking, cargo, insurance. Association rule mining can be defined as follows (Agrawal, 1993), (Liao, 2008),(Baralis, 1997),(Hsieh, 2004); 
Let $I=\left\{\mathrm{i}_{1}, \mathrm{i}_{2}, \ldots \ldots, \mathrm{i}_{\mathrm{m}}\right\}$ be an items set and $\mathrm{T}=\left\{\mathrm{t}_{1}, \mathrm{t}_{2, \ldots \ldots,} \mathrm{t}_{\mathrm{n}}\right\}$ be a transactions set. Each transaction can be stated as $t_{n} \subseteq I$. An association rule can be shown as; $X \rightarrow Y$ where $X \subset I_{s} Y \subset I$ and $X \cap Y=\emptyset$. A transaction $t_{i}$ contains $X$ if $X \subset t_{i}$. The success rate of an association rule can be determined by its support and confidence values.

Support and confidence values can be denoted as;

support $=\frac{(\mathrm{X} \cup \mathrm{Y}) \cdot \text { count }}{\mathrm{n}}$

confidence $=\frac{(X \cup Y) \cdot \text { count }}{X \cdot \text { count }}$

Siramkaya (2005) in his study; focused on news related to individuals and organizations in order to provide fast and effective access to visual and textual data in the press sources that are available on the internet and to extract meaningful and important information[22]. Apriori algorithm was used in the study. Also Kılınç (2009) in his study; produced rules by using apriori algorithm and applied these rules at production and quality data of an electronic firm [23]. Erpolat (2012) in his study, compared the Apriori and FP-Growth Algorithms by collecting the data obtained from the sales of an authorized service operating in the automotive sector in Turkey [21]. Doğrul et al. (2015) worked on traffic accidents that occurred in Çankırı and analyzed them with the association rules mining [24]. Söylemez, Doğan and Özcan (2016) conducted a rule extraction study using data mining techniques for traffic accidents in Ankara province [25].

\section{Materials and Methods}

In this study, frequent delay factors in Turkish construction projects were defined at first and meaningful relationships were tried to find between these factors and project characteristics. These relationships were embodied with some significant rules by the association algorithms. For this study; the project characteristics for 238 construction projects in Turkey were requested from local and private authorities. After eliminating, the projects which are annoted or have ongoing legal problems were removed. Finally, it has been benefited from the collected 74 public and private projects data in Turkey. These data titles were listed below;

- Contract start and end date

- Project duration

- Contract fee

- Contractor experience

- Owner type

- Total construction area

- Number of subcontractors

- Number of workers

- Delay duration

Beacuse the Apriori algorithm works efficiently with categorical data, the collected raw data are grouped in categorical form. Firstly, the values in the data are adapted to the analysis by various transformations. Factors used as input parameters are listed as follows;

- Contractor experience

- $\quad$ Spring Duration Rate: Spring duration (days) / Total construction duration (days)

- Summer Duration Rate: Summer duration (days) / Total construction duration (days)

- Fall Duration Rate : Fall duration (days) / Total construction duration (days)

- Winter Duration Rate : Winter duration (days) / Total construction duration (days)

- Unit Construction Cost $(\$ / \mathrm{m} 2)$ : Construction cost $(\$) /$ Total construction area (m2)

- Subcontractor Rate : Number of subworkers / Total construction area (m2)

- Worker Rate : Number of workers / Total construction area (m2)

- Delay Rate: Delay duration (days) / Total construction duration (m2)

Then the grouping has been done as follows:

If contractor experience is under 5 years the group category is "A", between 6 and 13 years is "B", between 14 and 23 years is "C", between 24 and 35 years is " $D$ ", and over 35 years is "E".

If spring duration rate is under $\% 20$ the group category is " $\mathrm{A}$ ", between $\% 21$ and $\% 24$ is " $\mathrm{B}$ ", between $\% 25$ and $\% 26$ is "C", between $\% 27$ and $\% 30$ is " $D$ ", and over \%31 is "E".

If summer duration rate is under $\% 20$ the group category is " $\mathrm{A}$ ", between $\% 21$ and \%25 is " $\mathrm{B}$ ", between \%26 and $\% 27$ is "C", between $\% 28$ and $\% 30$ is " $D$ ", and over $\% 31$ is "E". 
If fall duration rate is under $\% 18$ the group category is " $\mathrm{A}$ ", between $\% 19$ and $\% 24$ is " $\mathrm{B}$ ", between $\% 25$ and $\% 26$ is "C", between $\% 27$ and $\% 30$ is " $D$ ", and over \%31 is " $E$ ".

If winter duration rate is under $\% 22$ the group category is " $\mathrm{A}$ ", between $\% 23$ and $\% 24$ is "B", between $\% 25$ and $\% 28$ is "C", between \%29 and \%30 is " $\mathrm{D}$ ", over \%31 is " $\mathrm{E}$ ".

If Unit Construction Cost is under 35.88, the group category is " $\mathrm{A}$ ", between 35.88 and 136,43 is " $\mathrm{B}$ ", between 136,43 and 188,51 is "C", between 188,51 and 241,09 is " $D$ ", and over 241,09 is "E".

If Subcontractor Rate is under 0,0001 the group category is " $\mathrm{A}$ ", between 0,0002 and 0,0006 is "B", between 0,0007 and 0,0014 is "C", between 0,0015 and 0,0026 is " $D$ ", over 0,0027 is " $E$ ".

If Worker Rate is under 0,0015 the group category is " $\mathrm{A}$ ", between 0,0016 and 0,0029 is " $\mathrm{B}$ ", between 0,0030 and 0,0052 is " $C$ ", between 0,0053 and 0,0140 is " $D$ ", over 0,0141 is "E".

If delay rate is under $\% 1,10$ the group category is " $\mathrm{A}$ ", between $\% 1,11$ and $\% 4,64$ is " $\mathrm{B}$ ", between $\% 4,65$ and $\% 47,17$ is "C", between $\% 47,18$ and $\% 70,46$ is " $\mathrm{D}$ ", over $\% 70,47$ is " $\mathrm{E}$ ".

These grouped project factors are listed in Table 1.

Table 1. Grouping variables of project factors.

\begin{tabular}{|c|c|c|c|}
\hline Factor Name & Minimum & Maximum & Category \\
\hline \multirow{5}{*}{ Contractor experience } & 0 years & 5 years & $\mathrm{A}$ \\
\hline & 6 years & 13 years & B \\
\hline & 14 years & 23 years & $\mathrm{C}$ \\
\hline & 24 years & 35 years & $\mathrm{D}$ \\
\hline & 35 years & $\infty$ years & $\mathrm{E}$ \\
\hline \multirow{5}{*}{ Spring Duration Rate } & 0 & $\% 20$ & $\mathrm{~A}$ \\
\hline & $\% 21$ & $\% 24$ & $\mathrm{~B}$ \\
\hline & $\% 25$ & $\% 26$ & $\mathrm{C}$ \\
\hline & $\% 27$ & $\% 30$ & $\mathrm{D}$ \\
\hline & $\% 31$ & $\infty$ & $\mathrm{E}$ \\
\hline \multirow{5}{*}{ Summer Duration Rate } & 0 & $\% 20$ & $\mathrm{~A}$ \\
\hline & $\% 21$ & $\% 25$ & $\mathrm{~B}$ \\
\hline & $\% 26$ & $\% 27$ & $\mathrm{C}$ \\
\hline & $\% 28$ & $\% 30$ & $\mathrm{D}$ \\
\hline & $\% 31$ & $\infty$ & $\mathrm{E}$ \\
\hline \multirow{5}{*}{ Fall Duration Rate } & 0 & $\% 18$ & $\mathrm{~A}$ \\
\hline & $\% 19$ & $\% 24$ & $\mathrm{~B}$ \\
\hline & $\% 25$ & $\% 26$ & $\mathrm{C}$ \\
\hline & $\% 27$ & $\% 30$ & $\mathrm{D}$ \\
\hline & $\% 31$ & $\infty$ & $\mathrm{E}$ \\
\hline \multirow{5}{*}{ Winter Duration Rate } & 0 & $\% 22$ & $\mathrm{~A}$ \\
\hline & $\% 23$ & $\% 24$ & $\mathrm{~B}$ \\
\hline & $\% 25$ & $\% 28$ & $\mathrm{C}$ \\
\hline & $\% 29$ & $\% 30$ & $\mathrm{D}$ \\
\hline & $\% 31$ & $\infty$ & $\mathrm{E}$ \\
\hline \multirow{5}{*}{ Unit Construction Cost } & 0 & $35.88 \$$ & $\mathrm{~A}$ \\
\hline & $35.89 \$$ & $136.43 \$$ & $\mathrm{~B}$ \\
\hline & $136.44 \$$ & $188.51 \$$ & $\mathrm{C}$ \\
\hline & $188.52 \$$ & $241.09 \$$ & $\mathrm{D}$ \\
\hline & $241.10 \$$ & $\infty$ & $\mathrm{E}$ \\
\hline
\end{tabular}




\begin{tabular}{|c|c|c|c|}
\hline \multirow{5}{*}{ Subcontractor Rate } & 0 & $\% 0.01$ & $\mathrm{~A}$ \\
\hline & $\% 0.02$ & $\% 0.06$ & $\mathrm{~B}$ \\
\hline & $\% 0.07$ & $\% 0.14$ & $\mathrm{C}$ \\
\hline & $\% 0.15$ & $\% 0.26$ & $\mathrm{D}$ \\
\hline & $\% 0.27$ & $\infty$ & $\mathrm{E}$ \\
\hline \multirow{5}{*}{ Worker Rate } & 0 & $\% 0.15$ & $\mathrm{~A}$ \\
\hline & $\% 0.16$ & $\% 0.29$ & $\mathrm{~B}$ \\
\hline & $\% 0.30$ & $\% 0.52$ & $\mathrm{C}$ \\
\hline & $\% 0.53$ & $\% 1.40$ & $\mathrm{D}$ \\
\hline & $\% 1.41$ & $\infty$ & $E$ \\
\hline \multirow{5}{*}{ Delay Rate } & 0 & $\% 1.10$ & $\mathrm{~A}$ \\
\hline & $\% 1.11$ & $\% 4.64$ & $\mathrm{~B}$ \\
\hline & $\% 4.65$ & $\% 47.17$ & $\mathrm{C}$ \\
\hline & $\% 47.18$ & $\% 70.46$ & $\mathrm{D}$ \\
\hline & $\% 70.47$ & $\infty$ & $E$ \\
\hline
\end{tabular}

\section{Results and Discussion}

After performing the grouping, the analysis was started to extract hidden patterns using the Apriori algorithm. The results of the analysis are examined and most remarkable relationships are presented below(Table.2)(Fig.1).

\subsection{Spring Duration Rate and Delay Rate}

If the spring duration rate is in Group B, then sum of the possibility of being the delay rate is in Group A and $\mathrm{B}$ is about $66 \%$. That is, spring duration rate is between $\% 21$ and $\% 24$ then the probability of being delay rate under $4.64 \%$ is $66 \%$.

\subsection{Winter Duration Rate and Delay Rate}

If the winter duration rate is in Group A, then sum of the possibility of being the delay rate is in Group B and $\mathrm{C}$ is about $58 \%$. That is, winter duration rate is under $\% 23$ then the probability of being delay rate between $1.11 \%$ and $47.17 \%$ is $\% 58$.

\subsection{Contractor Experience and Delay Rate}

If the contractor experience is in Group A, then the possibility of being the delay rate is in Group B is about $47 \%$. That is, if the contractor experience is below 5, the probability of delay being between $1.11 \%$ and $4.64 \%$ is $57 \%$.

\subsection{Worker Rate and Delay Rate}

If the worker rate is in Group D, then the possibility of being the delay rate is in Group B is about $41 \%$. That is, if the worker rate is between 0,0053 and 0,0140 the probability of delay being between $1.11 \%$ and $4.64 \%$ is $52 \%$.

Table 2. Extracted rules and results.

$$
\text { Rules Results }
$$

$\begin{array}{lllll}\text { If } & \Rightarrow \text { Then } & \text { Confidence/ Support } & \text { Probability } \\ \text { Spring Duration Rate = B } & \Rightarrow & \text { Delay Rate = A or B } & 21 / 7 & \% 66 \\ \text { Winter Duration Rate = A } & \Rightarrow & \text { Delay Rate = B or C } & 24 / 7 & \% 58 \\ \text { Contractor Experience = A } & \Rightarrow & \text { Delay Rate = B } & 19 / 11 & \% 57 \\ \text { Worker Rate = D } & \Rightarrow & \text { Delay Rate = B } & 17 / 9 & \% 52\end{array}$




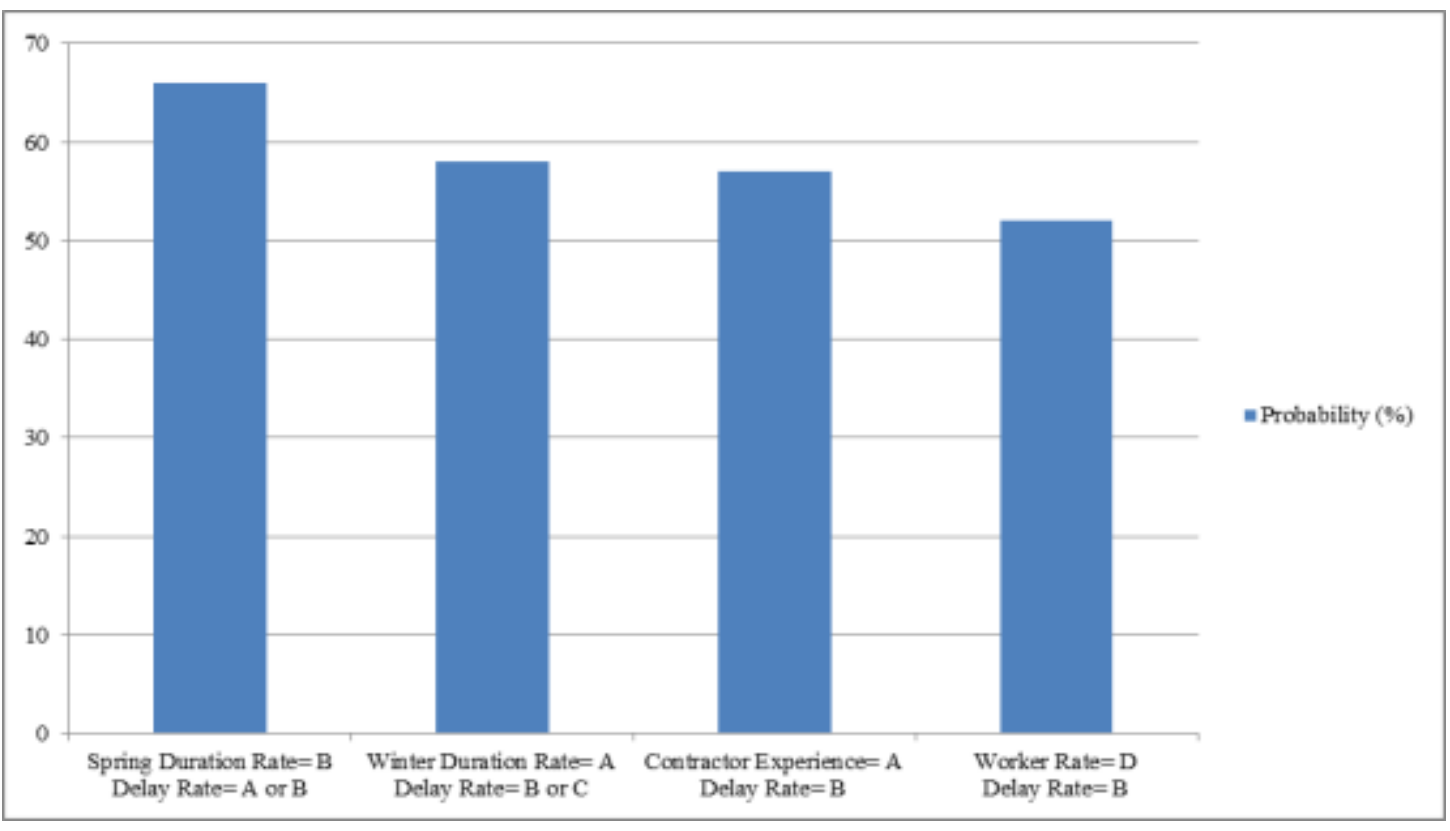

Fig.1 Probabilities for Extracted Rules

\section{Conclusions}

Since the delay in construction projects has an important place, it causes great economic and time losses. Therefore, many researches have been conducted to investigate delays in construction projects. As a difference, in this study, hidden relationships between project factors and delays were tried to find by applying apriori algorithm. As a result, factors which affect the delay most were found as contractor experience, number of workers, spring and winter durations. In the light of these rules, when proper working methods and plans are made in construction projects, delays could be prevented and a good progress could be made in terms of both time and material. Even limited data have been used in this study, some noteworthy rules were obtained. It is aimed to obtain more effective results by increasing the number of data in future studies.

\section{References}

1. Enshassi, A., Al-Hallaq, K., and Mohamed, S. (2006). Causes of Contractor's Business Failure in Developing Countries: The Case of Palestine, Journal of Construction Developing Countries, 11(2), 114.

2. Akogbe, R.K.T., Feng, X., Zhou, J., 2013. Importance and ranking evaluation of delay factors for development construction projects in Benin. KSCE Journal of Civil Engineering. 17 (6):1213-1222.

3. Olbak M ., Naimi, S. (2016). Kentsel Dönüşüm Uygulanmış 5 Katlı İki Yapı Örneğinin Deneysel Verileri Kullanılarak Doğrusal Olmayan Analiz Yöntemleri İle Güçlendirme Sonuçlarının İrdelenmesi. İstanbul Aydın Üniversitesi Dergisi, 8 (3), 145-166.

4. Mahamid, 2011. Common Risks Affecting Time Overrun in Road Construction Projects in Palestine: Contractors' Perspective, Australasian Journal Construction Economics Building this, vol. 13, no. 2, pp.45-53, 2011.

5. Kazaz, A., Ulubeyli, S. and Tuncbilekli, N.A., 2012. Causes of Delays in Construction Projects in Turkey, Journal of Civil Engineering and Management, 2012, 18(3): 426-435.

6. Marzouk, M.M. and El-Rasas, T.I., 2014, Analyzing delay causes in Egyptian construction projects, Journal of Advanced Research, Vol. 5 No.1, pp.49-55.

7. Trauner, J.T., Manginelli, W.A., Lowe, J.S., Nagata, M.F., Furniss, B.J., 2009. Construction Delays: understanding them clearly and Delay Analysis in Construction Analyzing them correctly.

8. Faridi, A.S., El-Sayegh, S.M., 2006. Significant factors causing delay in the UAE construction industry. Construction Management and Economics 24 (11):1167-1176.

9. Odeyinka, H.A. and Yusif, A., 1997, The causes and effects of construction delays on completion cost of housing projects in Nigeria, Journal of Financial Management of Property and Construction 1997, 2(3), 31-44.

10. Sambasivan M., Soon Y. W., 2007. Causes and Effects of Delays in Malaysian Construction İndustry, 
International Journal of Project Management 25 (2007) 517-526.

11. Zidane, Y.J-T., Andersen, B. 2018. The Top 10 Universal Delay Factors in Construction Projects, International Journal of Managing Projects in Business, Vol. 11 Issue: 3, pp.650-672.

12. Doloi, H., Sawhney, A., Iyer, K.C. and Rentala, S., 2012. Analysing factors affecting delays in Indian construction projects, International Journal of Project Management 30 (2012) 479-489.

13. Sunjka, B.P., Jacob, U. 2013. Significant causes and effects of project delays in the Niger Delta region, Nigeria, SAIIE25 Proceedings, 9th -11 th of July 2013, Stellenbosch.

14. Almutairi, N.S., 2016. Causes pf delays on construction projects in Kuwait according to opinion of engineers working in Kuwait, International Journal of Engineering Research and Application, ISSN: 2248-9622, Vol.6, Issue 12, (Part-3) December 2016, pp 84-96.

15. Rezaei, A., Jalal, S.,2018. Investigating the causes of delay and cost-overrun in construction industry, International Advanced Researches and Engineering Journal 02(02): 075-079, 2018.

16. Reihanifar M ., Naimi, S. (2016). Proje ve Maliyet Yönetimi Yöntemleriyle Kalitenin ve Verimliliğin Artırılmasının İncelenmesi. İstanbul Aydın Üniversitesi Dergisi, 8 (29), 51-65.

17. Reihanifar M ., Naimi, S. (2016). Evaluatıon of Road Construction Projects by Value Engıneerıng Approach as a Tool for Sustainability. International journal of ecosystems and ecology science (IJEES), 8 (2), 339-346.

18. Gülce, A.C., 2010. Veri Madenciliğinde Apriori Algoritması ve Apriori Algoritmasının Farklı Veri Kümelerinde Uygulanması, Trakya Üniversitesi Fen Bilimleri Enstitüsü, Bilgisayar Mühendisliği Ana Bilim Dalı, Yüksek Lisans Tezi.

19. Liao, C.W. and Perng, Y.H., 2007. Data mining for occupational injuries in the Taiwan construction industry. Safety Science, 46, 1091-1102.

20. Tsay, Y.J., Chiang, J.Y., 2005. CBAR: an efficient method for mining association rules. KnowledgeBased Systems 18, 99-105

21. Erpolat, S., 2012. Comparison of Apriori and FP-Growth Algorithms on Determination of Association Rules in Authorized Automobile Service Centres, Anadolu University Journal of Social Sciences, Vol. 12 No:1 (151-166) 137-146.

22. Sıramkaya, E., 2005. Veri Madenciliğinde Bulanık Mantık Uygulaması, Selçuk Üniversitesi, Fen Bilimleri Enstitüsü Yüksek Lisans Tezi.

23. Kılınç, Y., 2009. Mining Association Rules For Quality Related Data In An Electronics Company, Middle East Technical University, Industrial Engineering.

24. Doğrul, G., Akay, D., Kurt, M., 2015. Analysis of Traffic Accidents by Rules of Association, Gazi Journal of Engineering Sciences, 1/2 (2015) 265-284.

25. Söylemez, İ., Doğan A. and Özcan, U., 2016. Association Rules on Traffic Accident: Case of Ankara, Ege Academic Review, Cilt 16, Özel Sayı, 2016 ss. 11/20. 